\title{
Jaskra złośliwa: nowe poglądy na etiopatogenezę i postępowanie
}

\author{
Malignant glaucoma: new views on its etiopathogenesis and management
}

\section{Dorota Pożarowska, Tomasz Żarnowski}

Klinika Diagnostyki i Mikrochirurgii Jaskry, Uniwersytet Medyczny w Lublinie Kierownik: prof. dr hab. n. med. Tomasz Żarnowski

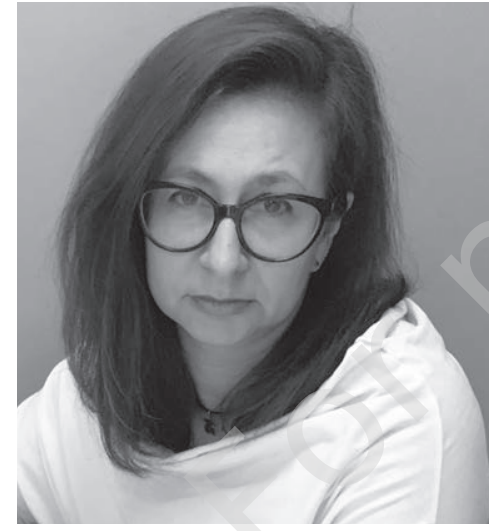

N A J W A Ż N I EJSZE Jaskra złośliwa jest rzadkim, ale potencjalnie oślepiającym powikłaniem procedur wewnątrzgałkowych. Dzięki wprowadzeniu nowych technik operacyjnych rokowanie w przypadku jej wystąpienia diametralnie się poprawiło.

\section{H I G H L I G H T S}

Malignant glaucoma is a rare but potentially blinding complication of intraocular procedures. The prognosis for this condition has diametrically improved due the development of new surgical techniques for its treatment.

\section{STRESZCZENIE}

Jaskra złośliwa jest rzadkim, ale poważnym powikłaniem operacji wewnątrzgałkowych. Najczęściej pojawia się po penetrujących zabiegach przeciwjaskrowych, ale może także wystąpić po każdej procedurze wewnątrzgałkowej. Jej obecność niosła ze sobą złą prognozę i bardzo wysokie ryzyko bolesnej ślepoty. Istotę choroby stanowi nieprawidłowy przepływ cieczy wodnistej w kierunku ciała szklistego, który doprowadza do przemieszczenia przepony soczewkowo-tęczówkowej lub tęczówkowo-szklistkowej ku przodowi i do zamknięcia kąta przesączania. Celem leczenia jest przywrócenie prawidłowego przepływu cieczy wodnistej i poprawa stosunków anatomicznych w gałce ocznej. W leczeniu stosowane są metody farmakologiczne (leki hamujące wytwarzanie cieczy wodnistej, cykloplegiki, leki osmotycznie czynne), techniki laserowe i chirurgiczne. Dzięki wprowadzeniu nowych technik operacyjnych, jak zonulokapsulohialoidowitrektomia, rokowanie w przypadku wystąpienia tego powikłania znacząco się poprawiło.

Słowa kluczowe: jaskra złośliwa, zespół nieprawidłowego przepływu cieczy wodnistej, blok rzęskowo-soczewkowy, blok tęczówkowo-rzęskowo-szklistkowy, zonulokapsulohialoidowitrektomia

\section{ABSTRACT}

Malignant glaucoma is a rare but serious complication of intraocular surgery. Most frequently it occurs after penetrating antiglaucoma procedures, but may also be present after intraocular procedures. Its presence ia associated with very bad prognosis with high risk of painful blindness. The essence of this disease is abnormal aqueous flow to vitreous cavity with leads to the forward displacement of iridolenticular or iridovitreal diaphragm and anterior angle closure. The crucial aim of treatment is to reverse abnormal aqueous flow and improve anterior segment anatomical relationships. Medical therapy (aqueous suppressants, cycloplegics, hyperosmotic agents), lasers techniques and surgery are used for this treatment. Due to the development of new surgical techniques the prognosis for malignant glaucoma has significantly improved.

Key words: malignant glaucoma, aqueous misdirection syndrome, lenticulociliary block, irido-vitreo-ciliary block, zonulo-capsulo-hyaloido-vitrectomy 


\section{WSTĘP}

Jaskra złośliwa jest jednym z rodzajów jaskry wtórnej zamykającego się kąta, a zarazem powikłaniem jatrogennym zabiegów wewnątrzgałkowych [1]. Jako pierwszy opisał ją już w 1868 r. von Graefe [2], a dodając do nazwy określenie złośliwy, pragnął podkreślić jej oporność na leczenie i trudności w postępowaniu w przypadku jej wystąpienia $[3,4]$. Naturalny przebieg schorzenia prowadzi do szybkiej, nieodwracalnej utraty widzenia, zniszczenia gałki ocznej (obrzęku i dekompensacji rogówki, powstania zrostów przednich i tylnych, zaćmy w oczach fakijnych, uszkodzenia nerwu wzrokowego), a w efekcie bolesnej jaskry dokonanej [1]. Mimo tak wielu lat, które upłynęły od pierwszego opisu schorzenia, możliwość wystąpienia tego zjawiska wciąż niepokoi chirurgów, zwłaszcza przedniego odcinka oka [3]. Jego patofizjologia nie jest w pełni wyjaśniona, a leczenie wciąż przysparza wielu trudności [3].

\section{OBRAZ KLINICZNY}

Klasyczny obraz jaskry złośliwej to oko po przebytym leczeniu zabiegowym, ze spłyconą obwodowo i centralnie (rozlanie) komorą przednią, bez bloku źrenicznego, tj. pomimo drożnej irydotomii lub irydektomii chirurgicznej, z wysokim lub - rzadziej - niskim ciśnieniem wewnątrzgałkowym, przy nieobecności odłączenia naczyniówki i/lub krwawienia nadnaczyniówkowego [3, 5-8] (ryc. 1,2). W skrajnych przypadkach komora przednia może być całkowicie zniesiona (ryc. 3). Objawy subiektywne moga być różnie nasilone: zwykle pacjent z „czerwonym okiem” skarży się na ból, pogorszenie widzenia, czasem z towarzyszącym bólem głowy i wymiotami [4]. Jeżeli możliwa jest ocena refrakcji chorego oka, to często obserwuje się jej przesunięcie w kierunku krótkowzroczności od -2,5 D do nawet -8 D (myopic shift) z powodu przesunięcia ku przodowi przepony soczewkowo-tęczówkowej $[4,7]$. Najczęściej powikłanie to występuje po perforujących zabiegach przeciwjaskrowych, takich jak: trabekulektomia, irydenklezja, wszczepienie sztucznych implantów drenujących (0,4-6\%) [1, 3, 4, 7, 9-11], ale też po zabiegach usunięcia zaćmy, witrektomii, przeszczepieniach rogówki, w oczach anatomicznie predysponowanych [3, 12-14]. W takich gałkach ocznych jaskra złośliwa pojawić się może też po mniej inwazyjnych procedurach, jak: operacje nieperforujące, zabiegi z rodzin miniinwazyjnej chirurgii zaćmy (MICS, mininally invasive cataract surgery), miniinwazyjnej chirurgii jaskry (MIGS, minimally invasive glaucoma surgery), wewnątrzgałkowych refrakcyjnych, a nawet lasero-

\section{RYCINA 1}

Jaskra złośliwa. Obraz przedniego odcinka oka. Kobieta 58-letnia. Stan po trabekulektomii z powodu pierwotnej jaskry zamykającego się kąta przesączania. Pseudofakia. A. Przedni odcinek oka. B. Poduszka filtracyjna. C. Spłycenie komory przedniej, widoczne irydotomia i irydektomia. D. Obraz W AS-OCTObra.
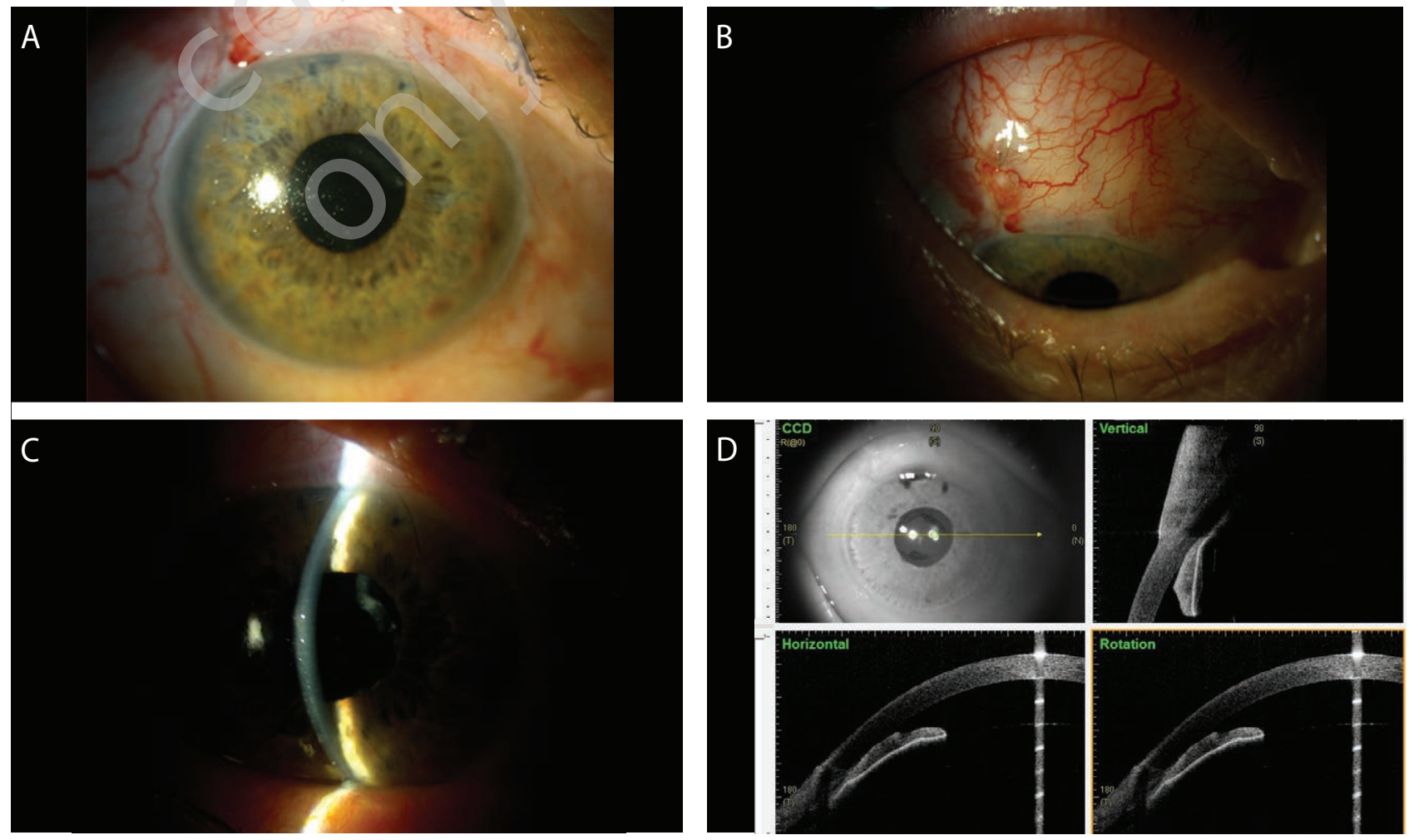


\section{RYCINA 2}

Jaskra złośliwa. Mężczyzna 65-letni. Pseudofakia. A. Przedni odcinek oka. B. Spłycenie komory przedniej. C. Obraz AS-OCT.
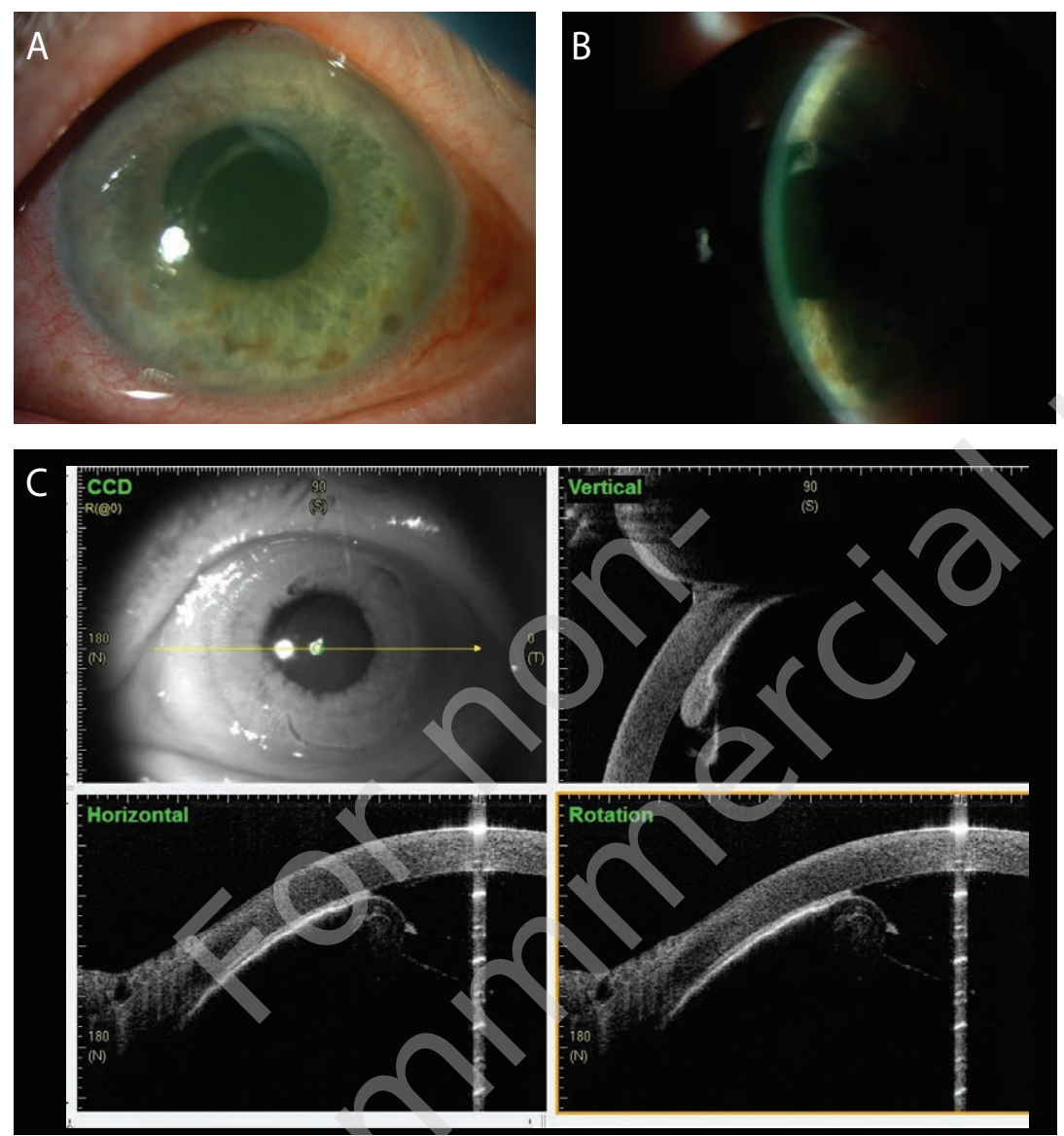

\section{RYCINA (3}

\section{Jaskra złośliwa. Obraz UBM. Kobieta 78-letnia. Stan po fakoemulsyfikacji zaćmy.} Zniesienie komory przedniej.
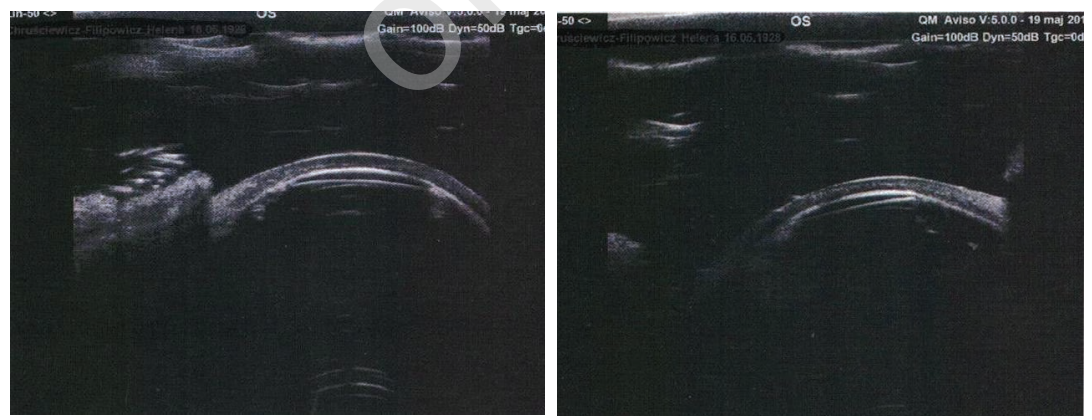

wych, jak: irydotomia, kapsulotomia, cyklofotokoagulacja czy suturoliza [1, 3, 4, 14-18]. Opisywano je również po intensywnym zastosowaniu miotyków lub jako zjawisko występujące całkowicie spontanicznie $[3,4,19,20]$. Pojawia się ono w bardzo różnym czasie po zabiegu pierwotnym - od pierwszej doby pooperacyjnej do nawet kilku lat po przebytym leczeniu operacyjnym [4].

\section{PATOMECHANIZM}

Pomimo że jaskra złośliwa to jednostka chorobowa znana od dawna, jej patomechanizm wciąż nie został w pełni i jednoznacznie wyjaśniony [4]. Prawdopodobnie etiopatogeneza schorzenia jest złożona i wieloczynnikowa. Wspólną cechę stanowi nieprawidłowy przepływ cieczy wodnistej, która nie mogąc przepłynąć ku przodowi do 
komory przedniej, płynie ku tyłowi gałki ocznej, gromadząc się w ciele szklistym, najprawdopodobniej na skutek bloku rzęskowo-soczewkowego w oczach fakijnych lub bloku tęczówkowo-rzęskowo-szklistkowego w oczach afakijnych lub pseudofakijnych [1, 5, 21]. Stąd też jednym z synonimów określających jaskrę złośliwą jest aqueous misdirection syndrome. Gromadzenie się cieczy wodnistej $\mathrm{w}$ ciele szklistym powoduje wzrost ciśnienia w komorze ciała szklistego, przesunięcie ku przodowi przepony soczewkowo-tęczówkowej i zamknięcie kąta przesączania (positive vitreous pressure glaucoma) [3, 4, 19, 22]. Chandler sugerował, że przesunięcie ku przodowi soczewki jest skutkiem wzrostu ciśnienia w ciele szklistym i wiotkości obwódki rzęskowej [22].

Wiele badań retrospektywnych zdefiniowało określoną budowę anatomiczną gałki ocznej jako czynnik ryzyka wystąpienia jaskry złośliwej [3, 23]. Zdecydowanie najczęściej rozwija się ona w oczach o krótkiej osiowej długości, z płytką komorą przednią, nadwzrocznością, wysokim indeksem soczewkowym, wąskim kątem przesączania, często po przebytym ostrym zamknięciu kąta i w oczach z pierwotną jaskrą zamykającego się kata przesączania [1, 3, 5, 8, 23-29]. Występuje ona częściej u Azjatów i kobiet, których gałki oczne mają statystycznie nieco mniejsze wymiary niż odpowiadające im wartości w oczach mężczyzn: płytsze komory przednie, węższy kąt przesączania i krótszą odległość pomiędzy równikiem soczewki a wyrostkami rzęskowymi [3, 4, 7, 28, 30].

Wystąpieniu jaskry złośliwej sprzyjają stany pooperacyjne przebiegające ze spłyceniem komory przedniej, jak hipotonia po trabekulektomii spowodowana przeciekiem z poduszki filtracyjnej lub hiperfiltracją [1]. Zauważono również, że w oczach dotkniętych tym schorzeniem występuje rotacja wyrostków rzęskowych ku przodowi [3, 5, 7, 29, 31]. Przypuszcza się też, iż zwiększona kondensacja przedniej części ciała szklistego powoduje zmniejszoną przepuszczalność szklistki i więźnięcie cieczy wodnistej w tylnej jej części, zwłaszcza w oczach z tylnym jej odłączeniem [3-5, 25]. Inną teorię tłumaczącą nieprawidłowy przepływ cieczy wodnistej ku tyłowi gałki ocznej przedstawił Quigley, wskazując, że rozszerzenie się, ekspansja naczyniówki może powodować wzrost ciśnienia w tylnym odcinku oka, co z kolei prowadzi do przesunięcia się ciała szklistego ku przodowi, następnie soczewki i tęczówki oraz zamknięcia kąta przesączania [1, 32-34]. Stwierdzono, że w niektórych oczach z jaskrą złośliwą dochodzi do uszkodzenia włókien kolagenowych substancji międzykomórkowej tkanki łącznej twardówki, wzrostu w niej fibronektyny i nieprawidłowego metabolizmu glikozaminoglikanów, czego następstwem jest wzrost grubości twardówki [1]. Zwiększenie grubości twardówki z kolei prowadzi do ucisku na żyły wirowate i upośledzenia żylnego drenażu naczyniówki, powodując jej przepełnienie
[1, 23, 32, 33]. Zjawisko to tłumaczy szczególną predyspozycję oczu z nanophthalmos do występowania w nich odłączenia naczyniówki, czyli zespołu wysiękowego błony naczyniowej (UES, uveal effusion syndrome), oraz jaskry złośliwej [23, 32, 33]. Co więcej, badania ultrabiomikroskopowe (UBM) oczu z jaskrą złośliwą oprócz przedniej rotacji wyrostków rzęskowych ujawniły częstą obecność w nich subklinicznego wysięku nadrzęskowego, nawet okrężnego [35, 36]. Czynnikami rozwoju jaskry złośliwej są też konfiguracja plateau iris oraz wystąpienie jaskry złośliwej w oku towarzyszącym [8].

\section{RÓŻNICOWANIE I OBRAZOWANIE}

Spłycenie komory przedniej z towarzyszącym (lub nie) wzrostem ciśnienia wewnątrzgałkowego charakterystyczne jest dla kilku stanów klinicznych. Zarówno ostre zamknięcie kąta z blokiem źrenicznym, jak i pierwotna jaskra zamykającego się kąta na tym tle przebiegają zwykle $\mathrm{z}$ niejednolitym spłyceniem, bardziej zaznaczonym na obwodzie komory, z obwodowym kontaktem rogówkowo-tęczówkowym włącznie, z zachowaną częściowo centralną głębokością tej komory [4]. Występowanie bloku źrenicznego można wykluczyć, stwierdzając obecność drożnej irydotomii laserowej lub irydektomii chirurgicznej, a w razie wątpliwości udrożniając je lub wręcz wykonując [4]. Hipotonia po zabiegach przeciwjaskrowych przebiegająca ze spłyceniem komory przedniej często jest następstwem hiperfiltracji lub przecieku z poduszki filtracyjnej. Dokładne badanie w lampie szczelinowej z wykonaniem testu Seidla z fluoresceiną zwykle pozwala je wykluczyć [4]. We wszystkich opisanych stanach konieczne jest również wnikliwe badanie tylnego odcinka oka w celu wykluczenia odłączenia naczyniówki, zarówno surowiczego, jak i krwotocznego, które również może zwiększyć ciśnienie w tylnym odcinku oka. Pozwala to nie tylko na prawidłową diagnozę, ale również na wdrożenie odpowiedniego leczenia [4]. Niezbędne jest zatem wykonanie badania ultrasonografii tylnego odcinka oka klasyczną sondą do projekcji B (10 MHz). Pomocna może też być ocena konfiguracji i zależności struktur przedniego odcinka oka za pomocą UBM i/lub AS-OCT [29, 35-37].

\section{POSTEPOWANIE}

Celem leczenia jaskry złośliwej jest nie tylko obniżenie ciśnienia wewnątrzgałkowego, ale i - przede wszystkim - odtworzenie prawidłowej anatomii oka, a więc konfiguracji komory przedniej [22]. Większość autorów zaleca stopniowe postępowanie, od leczenia farmakologicznego, poprzez zabiegi laserowe, do stosowania procedur chirurgicznych w opornych przypadkach [8, 38]. Terapię farmakologiczną stosuje się 3-5 dni przed decyzją o leczeniu chirurgicznym [4]. 
Opiera się ono na lekach zmniejszających produkcję cieczy wodnistej, takich jak $\beta$-blokery i inhibitory anhydrazy węglanowej podawane miejscowo i doustnie. Podanie silnych cykloplegików ma na celu naciągnięcie obwódki rzęskowej i przesunięcie przepony soczewkowo-tęczówkowej ku tyłowi oraz pogłębienie komory przedniej [3, 4, 39]. Dodatkowo stosuje się preparaty steroidowe, aby zmniejszyć towarzyszący odczyn zapalny. Podanie leków osmotycznie czynnych pomaga usunąć płyn z ciała szklistego [3-5]. Leczenie farmakologiczne, chociaż zmniejsza następstwa nieprawidłowego przepływu cieczy wodnistej, nie jest w stanie zmienić nieprawidłowych zależności na granicy soczewkatęczówka-wyrostki rzęskowe-ciało szkliste, dlatego też jego skuteczność wynosi ok. 50\%, a nawroty schorzenia po jego odstawieniu mogą sięgać nawet 100\% [3, 4, 8, 26, 40].

W przypadku niepowodzenia zachowawczego (farmakologicznego lub laserowego) leczenia jaskry złośliwej konieczne jest wdrożenie procedur chirurgicznych [41]. Pierwsza metoda takiego postępowania została zaproponowana już w roku 1964 przez Chandlera [42]. Opisał on skuteczność aspiracji cieczy wodnistej z ciała szklistego za pomocą igły $18 \mathrm{G}$ przez sklerektomię pod płatkiem twardówki ok. $2 \mathrm{~mm}$ za rąbkiem rogówki [42]. Skuteczność tych zabiegów nie była jednak znacząca. Spodziewano się, że wykonanie pełnej witrektomii przez pars plana w oczach zarówno fakijnych, jak i bez soczewki własnej (afakia/pseudofakia) będzie leczeniem radykalnym, które całkowicie rozwiąże problem nieprawidłowego gromadzenia się cieczy wodnistej i pozwoli odtworzyć prawidłową anatomię oka, a w rezultacie spowoduje obniżenie ciśnienia wewnątrzgałkowego. Jednakże skuteczność tych procedur okazała się niezadowalająca, a częstość nawrotów jaskry złośliwej po ich zastosowaniu sięgała nawet $66 \%$ [26].

Na podstawie obserwacji skuteczności opisanych powyżej procedur z biegiem czasu stało się jasne, iż kluczowym elementem skutecznego leczenia chirurgicznego jest nie tylko ewakuacja cieczy wodnistej z ciała szklistego, ale również stworzenie trwałej, wydolnej komunikacji pomiędzy przednim a tylnym odcinkiem oka, która zapobiegnie nieprawidłowemu przepływowi cieczy wodnistej i jej gromadzeniu się w ciele szklistym [3, 5, 9, 24-26, 28, 41, 43]. Jedną z takich metod może być mniej radykalna próba obwodowej kaspulotomii z hialoidotomią, przeprowadzona z irydotomią lub przez irydotomię/irydektomię wykonaną wcześniej laserem Nd:YAG, w oczach pseudo- i afakijnych [4, 5, 38, 44]. Ma ona za zadanie zniszczyć przednią powierzchnię ciała szklistego, uwolnić ciecz wodnistą z ciała szklistego i umożliwić jej przepływ do komory przedniej [4]. Skuteczność tej procedury nie jest jednak znacząca i nie wykonuje się jej w oczach fakijnych ze względu na zbyt wysokie ryzyko uszkodzenia soczewki [28, 26, 40]. Opisywano również pewne rezultaty po zastosowaniu laserowej cyklofotokoagulacji w celu obkurczenia wyrostków rzęskowych i przełamania bloku rzęskowego [5]. Istotne zatem jest usunięcie ciała szklistego z obszaru tworzonego połączenia pomiędzy przednim a tylnym odcinkiem gałki ocznej [5]. Skuteczność witrektomii przez pars plana w leczeniu jaskry złośliwej zwiększyła się aż do 100\% przez połączenie jej z wykonaniem irydektomii, kapsulektomii i zonulektomii [26]. Procedura taka, jakkolwiek radykalna, wymaga przeprowadzenia zabiegu przez chirurga witreoretinalnego. Jako że dla utrzymania drożności połączenia przedniego i tylnego odcinka oka w takiej procedurze kluczowe jest wycięcie tęczówki, torebki soczewki, obwódki rzęskowej i przylegającej części ciała szklistego, zaproponowano zabieg wykonywany przez chirurgów przedniego odcinka oka: zonulohialoidowitrektomię, w której wycięcie opisanych tkanek uzupełnia się o wykonanie witrektomii przedniej przylegającego do wycinanych tkanek ciała szklistego [3, 9, 24, 45, 46]. Najprościej zabieg ten przeprowadza się $\mathrm{z}$ dostępu przedniego, poprzez cięcie w rogówce, wprowadzając witrektom (20-25G) poprzez kanał wykonany igłą lub nożem, poprzez irydektomię, obwódkę rzęskową i torebkę do ciała szklistego $[3,9,24,40]$. Po przeprowadzeniu witrektomii przedniej witrektom wycofuje się powoli i wykonuje wycięcie torebki, obwódki i tęczówki $[9,24,40]$. Procedura może być połączona z jednoczesnym wykonaniem goniosynechiolizy [9, 24, 47]. Zabieg ten można również przeprowadzić od tyłu z dostępu od pars plana, wymaga jednak wprowadzenia do gałki ocznej trokarów przez pars plana $[3,5,28,48]$.

W oczach fakijnych zaleca się oprócz wykonania witrektomii usunięcie soczewki własnej [5, 21, 25]. Przeprowadzenie witrektomii bez jednoczesnej lensektomii miało znacząco niższy odsetek sukcesu niż procedura z nią połączona [21, 41]. W technice zaproponowanej przez Sharma i wsp. na początku zabiegu wykonuje się witrektomię przednią, pozwalającą pogłębić komorę przednią, a następnie fakoemulsyfikację z wszczepieniem sztucznej soczewki wewnątrzgałkowej i uzupełnienie witrektomii przedniej z zonulokapsulohialoidektomią [5, 25]. Niektórzy autorzy zalecają wykonanie witrektomii przedniej profilaktycznie przy operacji zaćmy u chorych, u których po operacji zaćmy w drugim oku obserwowano rozwój jaskry złośliwej [49]. W literaturze pojawiają się też propozycje metod chirurgicznych $\mathrm{z}$ zachowaniem soczewki własnej [50, 51].

Na sukces leczenia jaskry złośliwej składają się dwa elementy. Pierwszym z nich jest przerwanie mechanizmu bloku przepływu cieczy wodnistej z tylnej do przedniej części oka i odtworzenie prawidłowej anatomii gałki ocznej, a przynajmniej pogłębienie komory przedniej [3, 50] (ryc. 4, 5). Drugi element stanowi obniżenie ciśnienia wewnątrzgałkowego do poziomu ciśnienia docelowego (sukces całkowity bez zastosowania leków hipotonizujących lub częściowy $\mathrm{z}$ ich zastosowaniem) $[3,50]$. Pierwszy element wydaje się 
zasadniczy, gdyż w przypadku braku normalizacji ciśnienia wewnątrzgałkowego po uzyskaniu zwiększenia głębokości komory przedniej możliwe jest bezpieczne zastosowanie dodatkowych procedur chirurgicznych, takich jak: goniosynechioliza, trabekulektomia, wszczepienie implantów drenujących lub cyklofotodestrukcja w oczach z niskim potencjałem wzrokowym $[4,5,28]$.

\section{RYCINA 4}

Stan po zonulohialoidowitrektomii u pacjentki prezentowanej na rycinie 1 - obraz w AS-OCT. Pogłębienie komory przedniej.
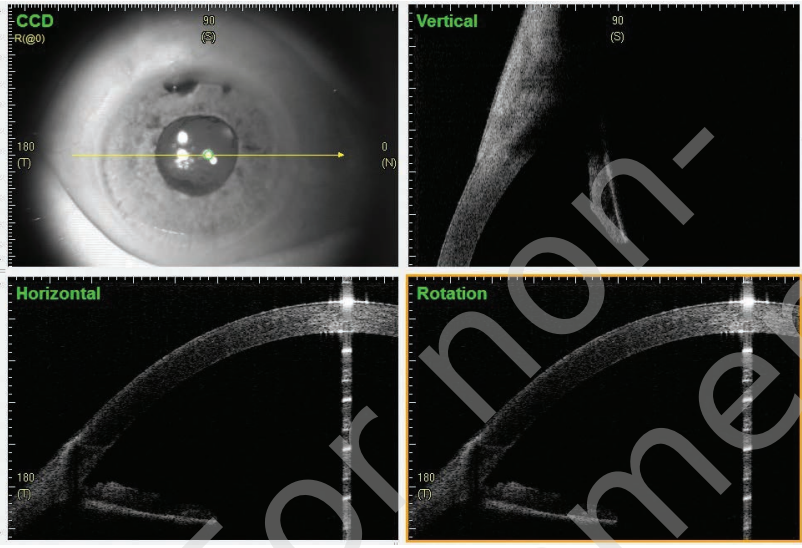

\section{RYCINA 5}

Stan po zonulohialoidowitrektomii u pacjenta prezentowanego na rycinie 2 - obraz w AS-OCT. Pogłębienie komory przedniej.
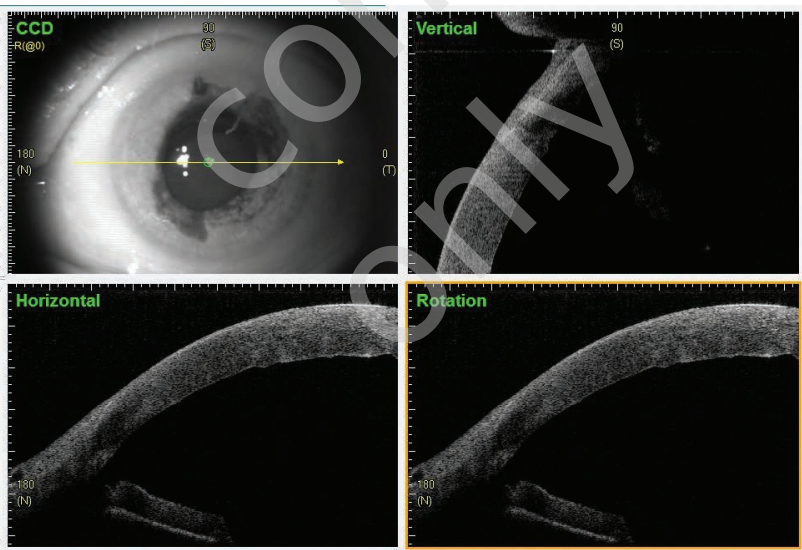

\section{ROKOWANIE}

Jaskra złośliwa jest schorzeniem, w którym rokowanie wyraźnie zmieniło rozwój medycyny. Początkowo charakteryzowano je jako stan doprowadzający prawie bezwzględnie do bolesnej utraty widzenia, co miała oddawać nazwa choroby. W dzisiejszych czasach jej oblicze wyraźnie złagodniało [3]. Rozwój technik diagnostycznych pozwala wyłonić grupy chorych z wysokim stopniem ryzyka jej wystąpienia i wdrożyć odpowiednie leczenie [7, 52-54]. Z kolei rozwój technik chirurgicznych umożliwił bezpieczne zastosowanie radykalnych metod $\mathrm{w}$ tym leczeniu, a następnie ponowne ich ulepszenie poprzez wprowadzenie procedur równie radykalnych, ale o wiele mniejszym zakresie przy większym profilu bezpieczeństwa [9, 24]. Niektórzy specjaliści zalecają także prewencyjne stosowanie bardziej radykalnych metod przy zidentyfikowaniu wysokiego ryzyka jaskry złośliwej, zwłaszcza przy leczeniu drugiego oka, w przypadkach gdy po leczeniu oka pierwszego doszło do rozwoju jaskry złośliwej [49, 53, 54].

\section{PODSUMOWANIE}

Podsumowując, nowoczesna wiedza, diagnostyka i możliwości chirurgiczne pozwalają obecnie na szybkie rozpoznanie jaskry złośliwej i wdrożenie radykalnego, bezpiecznego leczenia dającego możliwość utrzymania wzrokowych parametrów funkcjonalnych.

Ryciny 1, 2, 4, 5 opublikowano dzięki uprzejmości dr n. med. Agnieszki Wilkos-Kuc.

\section{ADRES DO KORESPONDENCJI}

\section{dr n. med. Dorota Pożarowska}

Klinika Diagnostyki i Mikrochirurgii Jaskry,

Uniwersytet Medyczny w Lublinie

20-079 Lublin, ul. Chmielna 1

e-mail:dpozarowska@wp.pl
ORCID:

Dorota Pożarowska - ID - orcid.org/0000-0001-6222-7858

Tomasz Żarnowski - ID - orcid.org/0000-0002-6978-7417 


\section{Piśmiennictwo}

1. Krix-Jachym K, Żarnowski T, Rękas M. Risk Factors of Malignant Glaucoma Occurrence after Glaucoma Surgery. J Ophthalmol 2017; 2017: 9616738.

2. Graefe A. Beiträge zur Pathologie und Therapie des Glaucoms. Albrecht von Graefes Archiv für Ophthalmologie 1869; 15: $108-252$.

3. Grzybowski A, Kanclerz P. Acute and chronic fluid misdirection syndrome: pathophysiology and treatment. Graefes Arch Clin Exp Ophthalmol 2018; 256(1): 135-154.

4. Foreman-Larkin J, Netland PA, Salim S. Clinical Management of Malignant Glaucoma. J Ophthalmol 2015; 2015: 283707. DOI: 10.1155/2015/283707. Epub 2015 Dec 24

5. Balekudaru S, Choudhari NS, Rewri P, et al. Surgical management of malignant glaucoma: a retrospective analysis of fifty eight eyes. Eye (Lond). 2017; 31(6): 947-955.

6. Burgansky-Eliash Z, Ishikawa H, Schuman JS. Hypotonous malignant glaucoma: aqueous misdirection with low intraocular pressure. Ophthalmic Surg Lasers Imaging 2008; 39(2): 155-159.

7. Sahoo NK, Balijepalli P, Singh SR, et al. Retina and glaucoma: surgical complications. Int J Retina Vitreous 2018; 4: 29.

8. Kaplowitz K, Yung E, Flynn R, et al. Current concepts in the treatment of vitreous block, also known as aqueous misdirection. Surv Ophthalmol 2015; 60(3): 229-241.

9. Rękas M, Krix-Jachym K, Żarnowski T. Evaluation of the Effectiveness of Surgical Treatment of Malignant Glaucoma in Pseudophakic Eyes through Partial PPV with Establishment of Communication between the Anterior Chamber and the Vitreous Cavity. J Ophthalmol 2015; 2015: 873124.

10. Greenfield DS, Tello C, Budenz DL, et al. Aqueous misdirection after glaucoma drainage device implantation. Ophthalmology 1999; 106(5): 1035-1040.

11. Shahid H, Salmon JF. Malignant glaucoma: a review of the modern literature. J Ophthalmol 2012; 2012: 852659.

12. Ghoraba HH, Ghali AA, Mansour HO. Aqueous misdirection following pars planavitrectomy and silicone oil injection. Clin Ophthalmol 2015; 9: 903-906.

13. Varma DK, Belovay GW, Tam DY, et al. Malignant glaucoma after cataract surgery. J Cataract Refract Surg 2014; 40(11): $1843-1849$.

14. Francis BA, Babel D. Malignant glaucoma (aqueous misdirection) after pars planavitrectomy. Ophthalmology 2000; 107(7): 1220-1222.

15. Montolío Marzo S, Lanzagorta Aresti A, Davó Cabrera JM, et al. Malignant glaucoma after XEN45 implant. Arch Soc Esp Oftalmol 2019; 94(3): 134-137.

16. Senthil S, Choudhari NS, Vaddavalli PK, et al. Etiology and Management of Raised Intraocular Pressure following Posterior Chamber Phakic Intraocular Lens Implantation in Myopic Eyes. PLoS One 2016; 11(11): e0165469.

17. Arya SK, Sonika, Kochhar S, et al. Malignant glaucoma as a complication of Nd:YAG laser posterior capsulotomy. Ophthalmic Surg Lasers Imaging 2004; 35(3): 248-250.

18. Greenfield JA, Smiddy WE, Greenfield DS. Malignant Glaucoma After Laser Peripheral Iridotomy. J Glaucoma 2019; 28 (3): e44-e45.

19. Premsenthil M, Salowi MA, Siew CM, et al. Spontaneous malignant glaucoma in a patient with patent peripheral iridotomy. BMC Ophthalmol 2012; 12:64.

20. Brooks AM, Harper CA, Gillies WE. Occurrence of malignant glaucoma after laser iridotomy. Br J Ophthalmol 1989; 73(8): 617-620.

21. Harbour JW, Rubsamen PE, Palmberg P. Pars planavitrectomy in the management of phakic and pseudophakic malignant glaucoma. Arch Ophthalmol 1996; 114(9): 1073-1078.

22. Chandler PA. Malignant glaucoma. Am J Ophthalmol 1951; 34(7): 993-1000.

23. Faucher A, Hasanee K, Rootman DS. Phacoemulsification and intraocular lens implantation in nanophthalmic eyes: report of a medium-size series. J Cataract Refract Surg 2002; 28(5): 837-842.

24. Żarnowski T, Wilkos-Kuc A, Tulidowicz-Bielak M, et al. Efficacy and safety of a new surgical method to treat malignant glaucoma in pseudophakia. Eye (Lond) 2014; 28(6): 761-764. DOI: 10.1038/eye.2014.53. Epub2014 Mar 14.

25. Sharma A, Sii F, Shah P, et al. Vitrectomy-phacoemulsification-vitrectomy for the management of aqueous misdirection syndromes in phakic eyes. Ophthalmology 2006; 113(11): 1968-1973.

26. Debrouwere V, Stalmans P, Van Calster J, et al. Outcomes of different management options for malignant glaucoma: a retrospective study. Graefes Arch Clin Exp Ophthalmol 2012; 250(1): 131-41.

27. Prata TS, Dorairaj S, De Moraes CG, et al. Is preoperative ciliary body and iris anatomical configuration a predictor of malignant glaucoma development? Clin Exp Ophthalmol 2013; 41(6): 541-545.

28. He F, Qian Z, Lu L, et al. Clinical efficacy of modified partial pars plana vitrectomy combined with phacoemulsification for malignant glaucoma. Eye (Lond) 2016; 30(8): 1094-1100.

29. Wang Z, Huang J, Lin J, et al. Quantitative measurements of the ciliary body in eyes with malignant glaucoma after trabeculectomy using ultrasound biomicroscopy. Ophthalmology 2014; 121(4): 862-869.

30. Razeghinejad MR, Amini H, Esfandiari H. Lesser anterior chamber dimensions in women may be a predisposing factor for malignant glaucoma. Med Hypotheses 2005; 64(3): 572-574.

31. Heindl LM, Koch KR, Cursiefen C, et al. Optical coherence tomography and ultrasound biomicroscopy in the management of pseudophakic malignant glaucoma. Graefes Arch Clin Exp Ophthalmol 2013; 251(9): 2261-2263. 
32. Quigley HA, Friedman DS, Congdon NG. Possible mechanisms of primary angle-closure and malignant glaucoma. J Glaucoma 2003; 12(2): 167-180.

33. Quigley HA. Angle-closure glaucoma-simpler answers to complex mechanisms: LXVI Edward Jackson Memorial Lecture. Am J Ophthalmol 2009; 148(5): 657-669.e1.

34. Chen X, Guo X, Xu X, et al. Is Thicker Choroid a Risk Factor for Malignant Glaucoma? Ophthalmic Res 2018; 60(3): 161-168.

35. Trope GE, Pavlin CJ, Bau A, et al. Malignant glaucoma. Clinical and ultrasound biomicroscopic features. Ophthalmology 1994; 101(6): 1030-1035.

36. Liebmann JM, Weinreb RN, Ritch R. Angle-closure glaucoma associated with occult annular ciliary body detachment. Arch Ophthalmol 1998; 116(6): 731-775.

37. Wirbelauer $\mathrm{C}$, Karandish A, Häberle $\mathrm{H}$, et al. Optical coherence tomography in malignant glaucoma following filtration surgery. Br J Ophthalmol 2003; 87(8): 952-955.

38. Wu ZH, Wang YH, Liu Y. Management strategies in malignant glaucoma secondary to antiglaucoma surgery. Int J Ophthalmol. 2016; 9(1): 63-68.

39. Chandler PA, Simmons RJ, Grant WM. Malignant glaucoma. Medical and surgical treatment. Am J Ophthalmol 1968; 66(3): 495-502.

40. Pakravan M, Esfandiari H, Amouhashemi N, et al. Mini-vitrectomy; a Simple Solution to a Serious Condition. J Ophthalmic Vis Res 2018; 13(3): 231-235.

41. Tsai JC, Barton KA, Miller MH, et al. Surgical results in malignant glaucoma refractory to medical or laser therapy. Eye (Lond) 1997; 11(Pt 5): 677-681.

42. Chandler PA. A New Operation for Malignant Glaucoma: a Preliminary Report. Trans Am Ophthalmol Soc 1964; 62: 408-424.

43. Dave $P$, Rao A, Senthil $S$, et al. Recurrence of aqueous misdirection following pars plana vitrectomy in pseudophakic eyes. BMJ Case Rep 2015; 2015. pii: bcr2014207961.

44. Little BC, Hitchings RA. Pseudophakic malignant glaucoma: Nd:YAG capsulotomy as a primary treatment. Eye (Lond) 1993; 7(Pt 1): 102-104.

45. Madgula IM, Anand N. Long-term follow-up of zonulo-hyaloido-vitrectomy for pseudophakic malignant glaucoma. Indian J Ophthalmol 2014; 62(12): 1115-1120.

46. Lois N, Wong D, Groenewald C. New surgical approach in the management of pseudophakic malignant glaucoma. Ophthalmology 2001; 108(4): 780-783.

47. Tang J, Du E, Li X. Combined Surgical Techniques for the Management of Malignant Glaucoma. J Ophthalmol 2018; $2018: 9189585$.

48. Meng L, Wei W, Li Y, et al. 25-Gauge pars plana vitrectomy for ciliary block (malignant) glaucoma. Int Ophthalmol 2015; 35(4): 487-493.

49. Chaudhry NA, Flynn HW Jr, Murray TG, et al. Pars plana vitrectomy during cataract surgery for prevention of aqueous misdirection in high-risk fellow eyes. Am J Ophthalmol 2000; 129(3): 387-388.

50. Yu J, Chen X, Zhou D, et al. Clinical Efficacy of Ciliary Ring Incision Combined with Modified Partial Pars Plana Vitrectomy for Malignant Glaucoma. Med Sci Monit 2018; 24: 3916-3921.

51. Rani PK, Gulati I, Rao HL, et al. 25g pars plana vitrectomy and irido-zonulo-hyaloido-vitrectomy in the management of malignant glaucoma in phakic eyes following trabeculectomy. Retin Cases Brief Rep 2018; 12(1): 33-35.

52. Graber M, Khoueir Z, Beauchet A, et al. High intensity focused ultrasound as first line treatment in patients with chronic angle closure glaucoma at risk for malignant glaucoma. J Fr Ophtalmol 2017; 40(4): 264-269.

53. Thompson AC, Challa P. Prophylactic anterior vitrectomy during cataract surgery in eyes at increased risk for aqueous misdirection. Am J Ophthalmol Case Rep 2018; 12: 24-27.

54. Pathak Ray V, Gulati I, Choudhari N. Intra-Operative Ostial Irido-Zonulo-Hyaloido-Vitrectomy with Primary Posterior Capsulectomy for Prevention of Post-Operative Aqueous Misdirection in Combined Phaco-Trabeculectomy in Primary Angle Closure Glaucoma. Curr Eye Res 2019: 1-4. 